\title{
AKTIVITAS ANTIBAKTERI KULIT BATANG LIBO (Ficus variegate Blume)
}

\author{
Rizka Amelia Saleh, Agung Rahmadani, Lizma Febrina, Rolan Rusli* \\ Laboratorium Penelitian dan Pengembangan FARMAKA TROPIS Fakultas Farmasi \\ Universitas Mulawarman, Samarinda, Kalimantan Timur \\ *email: rizkaamelia703@gmail.com
}

\begin{abstract}
An antimicrobial agent is a natural component of semi-synthetic or synthetic that can interfere metabolism and inhibit the growth or kill the microbes. Antimicrobial agents can be derived from synthetic or chemical compounds from plants. One of the plants that can be used as an antimicrobial material is bark libo who has phenols, tannins and alkaloids. The aims of this research was to determine antibacterial activity and the effective concentration from methanol extract and n-butanol fraction of bark libo using discdiffusion method by observing Minimum Bactericidal Concentration (MBC). Bacteria tested were Escherichia coli and Staphylococcus aureus. Concentrations of methanol extract used were 1\%, 5\%,10\% and $15 \%$. Whilst Concentrations of fraction of n-butanol used were $0.25 \%, 0.5 \%, 1 \%, 1.5 \%$ and $2 \%$. The results showed that bark libo has antibacterial activity, indicated by a clear zone around paperdisk. The results was analyzed using one-way ANOVA and advanced test Duncan's Multiple Range Test (DUNCAN). The result showed that there was no significant difference $(p>0.05)$ from variation concentration of $n$-butanol fraction in inhibiting the growth of $E$. coli and $S$. aureus, whereas for the methanol extract, there were significant differences $(p<0.05)$ in inhibiting $S$. aureus bacterial growth. The effective concentration of the methanol extract was $10 \%$ for antibacterial agents.
\end{abstract}

Key words: Antibacterial, Bark Libo, Minimum Bactericidal Concentration (MBC)

\begin{abstract}
ABSTRAK
Bahan antimikroba merupakan komponen alam semisintesis atau sintesis yang dapat mengganggu metabolisme dan menghambat pertumbuhan atau membunuh mikroba. Bahan antimikroba dapat berasal dari senyawa kimia sintesis atau dari tumbuhan. Salah satu tanaman yang dapat digunakan sebagai bahan antimikroba adalah kulit batang libo yang mengandung fenol, tanin dan alkaloid. Penelitian ini bertujuan untuk mengetahui aktivitas antibakteri dan konsentrasi efektif dari ekstrak metanol dan fraksi n-butanol kulit batang libo menggunakan metode disc-diffusion dengan mengamati Konsentrasi Bunuh Minimum (KBM). Bakteri yang diujikan adalah Eschericia coli dan Staphylococcus aureus. Bakteri yang diujikan adalah Eschericia coli dan Staphylococcus aureus. Konsentrasi ekstrak metanol yang digunakan adalah 1\%, 5\%, 10\% dan 15\% sedangkan konsentrasi fraksi nbutanol yang digunakan adalah $0,25 \%, 0,5 \%, 1 \%, 1,5 \%$ dan $2 \%$.. Hasil penelitian menunjukkan adanya potensi antibakteri pada kulit batang libo yang ditunjukkan dengan adanya zona bening di sekitar paperdisk. Hasil uji kemudian dianalisis menggunakan ANAVA satu arah serta uji lanjutan Beda Nyata Jujur Duncan. Hasil analisis data menunjukkan bahwa tidak ada perbedaan signifikan $(\mathrm{p}>0,05)$ konsentrasi uji pada fraksi n-butanol dalam menghambat pertumbuhan bakteri E.coli maupun S.aureus namun
\end{abstract}


terdapat perbedaan signifikan $(\mathrm{p}<0,05)$ untuk ekstrak metanol dalam menghambat pertumbuhan bakteri S.aureus. Konsentrasi efektif ekstrak metanol kulit batang libo sebagai antibakteri adalah $10 \%$.

Kata kunci : Antibakteri, Kulit batang libo, Konsentrasi Bunuh Minimum (KBM)

\section{PENDAHULUAN}

Penyakit infeksi yang disebabkan oleh bakteri masih menjadi masalah kesehatan bagi masyarakat baik di Indonesia maupun di Negara lainnya. Secara umum infeksi ini disebabkan oleh bakteri, jamur, virus, dan parasit [1].

Escherichia coli dan Staphylococcus aureus merupakan bakteri yang seringkali menyebabkan penyakit pada masyarakat. Beberapa penyakit yang disebabkan oleh E.coli antara lain, diare, infeksi saluran kemih, infeksi saluran napas, infeksi pembuluh darah, sedangkan S.aureus dapat menyebabkan pneumonia, infeksi tulang dan sendi, serta infeksi pada valvula jantung [2]. Menurut data dari WHO pada tahun 2013, diare dan pneumonia termasuk ke dalam sepuluh penyakit yang menyebabkan kematian dimana kedua penyakit tersebut disebabkan oleh bakteri E.coli dan S.aureus.

Antibiotik digunakan sebagai penanganan utama pada penyakit infeksi, namun penggunaannya yang salah dan secara terus menerus dapat menyebabkan terjadinya resistensi. Menurut penelitian dari Antimicrobial resistant in Indonesia (AMRIN-Study), terbukti dari 2494 individu di masyarakat, 43\% Escherichia coli resisten terhadap jenis antibiotik tertentu antara lain: ampisilin (34\%), kotrimoksazol (29\%) dan kloramfenikol (25\%). Dan menurut Emerging Resistance Pathogen, Staphylococcus aureus telah resisten terhadap penisilin, oksasilin, ciprofloksasin dan metisilin serta antibiotik beta laktam lainnya [3].

Angka resistensi terhadap antbiotik terus meningkat, sehingga dibutuhkan alternatif lain untuk menangani infeksi bakteri tersebut. Alternatif yang dapat digunakan salah satunya adalah Libo (Ficus variegate Blume). Tumbuhan Libo merupakan tumbuhan asli dari Kalimantan Timur dimana buah dan daunnya telah diteliti dan memiliki aktivitas sebagai antioksidan dan antibakteri [4]. Namun pengujian terhadap kulit batang libo belum dilakukan, sehingga peneliti tertarik untuk menguji aktivitas antibakteri dari ekstrak metanol dan fraksi n-butanol kulit batang libo terhadap bakteri Eschericia coli dan Staphylococcus aureus

\section{METODE PENELITIAN}

\section{Bahan}

Kulit batang libo, metanol, n-heksan, etil asetat, n-butanol, asam klorida pekat, serbuk magnesium, besi (III) klorida, asam asetat glasial, asam sulfat pekat, pereaksi Mayer dan Dragendorff, medium NA (Nutrient Agar), bakteri Escherichia coli dan Staphylococcus aureus, paper disc, $\mathrm{NaCl}$ 0,9\%, aquades, alkohol $70 \%$.

\section{Peralatan}

Alat yang digunakan adalah alat kaca dan alat non kaca, timbangan analitik $\left(\right.$ Precisa $\left.^{\circledR}\right)$, inkubator $\left(\right.$ Frailabo $\left.^{\circledR}\right)$, autoklaf (Tomy SN-700), LAF (Laminar Air Flow) (Nuarire-126-400E), dan mikrometer sekrup (Insize $\left.{ }^{\circledR}\right)$. 


\section{Prosedur Kerja}

Kulit batang libo yang telah dibuat menjadi simplisia, diekstraksi menggunakan metode maserasi dengan pelarut $n$-heksan kemudian dimaserasi kembali dengan pelarut metanol selama \pm 3 hari. Lalu disaring filtrat dan dipekatkan dengan rotary evaporator sehingga diperoleh ekstrak kental metanol kulit batang libo. Lalu ekstrak kental metanol difraksinasi menggunakan corong pisah dengan menggunakan pelarut n-heksan, etil asetat dan n-butanol. Kemudian dilakukan uji metabolit sekunder dengan mengamati adanya perubahan warna dan terbentuknya endapan menggunakan reagen kimia. Golongan metabolit sekunder yang diuji adalah alkaloid, flavonoid, tanin, fenol dan saponin dimana metode uji yang dilakukan sesuai dengan pengujian oleh Febrina, 2015.

Uji aktivitas antibakteri dilakukan dengan metode disc-diffusion menggunakan paper disc yang telah direndam kedalam larutan konsentrasi uji. Sebanyak 0,02 mL suspensi bakteri dimasukkan ke dalam cawan petri steril dengan cara aseptik. Kemudian dituang medium NA cair ke dalam cawan petri sebanyak $10 \mathrm{~mL}$. Setelah setengah memadat, paper disc yang mengandung konsentrasi uji dan aquades sebagai control negatif diletakkan pada permukaan medium secara teratur. Lalu diinkubasi di dalam inkubator selama 24 jam pada suhu $37^{\circ} \mathrm{C}$. Diamati zona hambat / bunuh yang terbentuk dan diukur daerah hambatan dengan menggunakan mikrometer sekrup.

\section{HASIL DAN PEMBAHASAN}

\section{Uji Metabolit Sekunder}

Hasil uji metabolit sekunder menunjukan bahwa ekstrak metanol kulit batang libo mengandung senyawa alkaloid, fenol dan tanin. Metabolit sekunder pada tumbuhan berfungsi untuk mempertahankan diri dari kondisi lingkungan yang kurang menguntungkan, misalnya respon untuk mengatasi hama dan penyakit.

Pengujian alkaloid yang dilakukan dengan pereaksi Dragendorff menghasilkan endapan berwarna jingga sedangkan dengan pereaksi Mayer akan menghasilkan endapan berwarna putih kekuningan. Senyawa alkaloid memiliki mekanisme penghambatan dengan cara mengganggu komponen penyusun peptidoglikan pada sel bakteri, sehingga lapisan dinding sel tidak terbentuk secara utuh dan mengakibatkan kematian sel [5]. Pada pengujian fenol menghasilkan larutan berwarna hijau atau biru sampai hitam. Fenol merupakan senyawa yang bekerja dengan cara denaturasi protein sel dan merusak embran sel. Sehingga senyawa fenol merupakan salah satu senyawa yang dapat digunakan sebagai antibakteri. Hasil uji tanin menghasilkan larutan bewarna biru atau hitam kehijauan. Mekanisme kerja tanin yaitu dengan mengkerutkan dinding sel atau membran sel sehingga mengganggu permeabilitas sel itu sendiri. Akibat terganggunya permeabilitas, sel tidak dapat melakukan aktivitas hidup sehingga pertumbuhannya akan terhambat dan mati [6]. Tabel 1 menunjukan hasil pengujian metabolit sekunder ekstrak metanol kulit batang libo.

Tabel 1. Hasil Uji Metabolit Sekunder Ekstrak Metanol Kulit Batang Libo

\begin{tabular}{lll}
\hline No & Uji & Hasil \\
\hline 1. & Alkaloid & + \\
2. & Saponin & - \\
3. & Tanin & + \\
4. & Flavonoid & - \\
5. & Fenol & + \\
\hline
\end{tabular}

Keterangan : Tidak Terdeteksi (-), Senyawa Terdeteksi (+) 


\section{Uji Aktivitas Antibakteri}

Pengujian aktivitas antibakteri ekstrak mertanol dan fraksi n-butanol kulit batang libo dilakukan dengan metode disc diffusion menggunakan bakteri Eschericia coli dan Staphylococus aureus. Untuk ekstrak metanol dilakukan pengujian dengan menggunakan konsentrasi 1\%,5\%, 10\% dan 15\% dan fraksi n-butanol menggunakan konsentrasi 0,25\%, $0,5 \%, 1 \%, 1,5 \%$ dan $2 \%$. Metode difusi yang dilakukan menggunakan paper disc dengan diameter $6 \mathrm{~mm}$ yang dicelupkan pada ekstrak kulit batang libo yang telah diencerkan dengan aquadest. Pengamatan dilakukan setelah bakteri $S$. aureus dan E. coli diinkubasi selama 24 jam pada suhu $37^{\circ} \mathrm{C}$.

Hasil pengujian aktivitas antibakteri ekstrak metanol kulit batang libo terhadap bakteri Staphylococcus aureus dan fraksi n-butanol terhadap bakteri Eschericia coli dan Staphylococus aureus terlihat pada Gambar 1,2 dan 3 yaitu terdapat zona bening disekitar paper disc dan membuktikan adanya aktivitas antibakteri pada sampel.

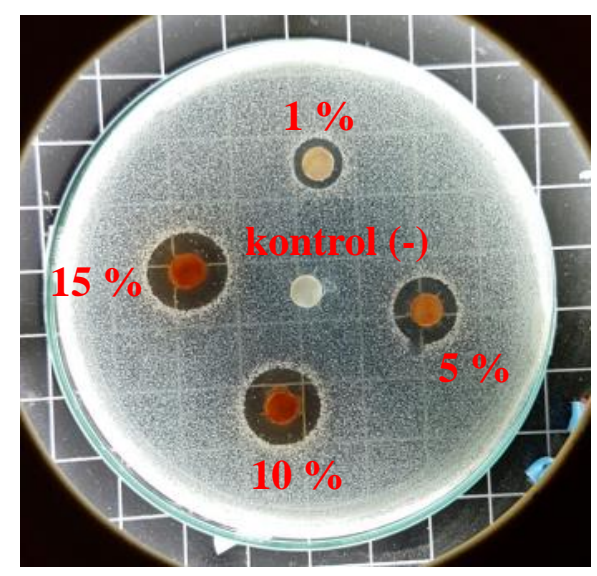

Gambar 1. Aktivitas Antibakteri Ekstrak Metanol Kulit Batang Libo terhadap bakteri S.aureus

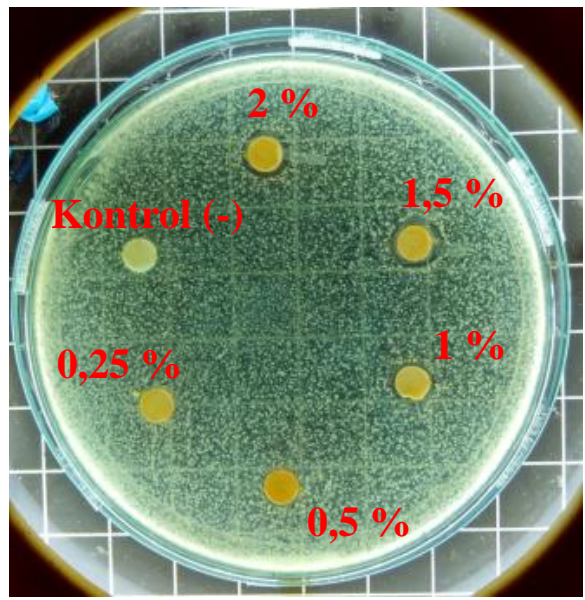

Gambar 2. Aktivitas Antibakteri Fraksi n-butanol Kulit Batang Libo terhadap bakteri S.aureus 


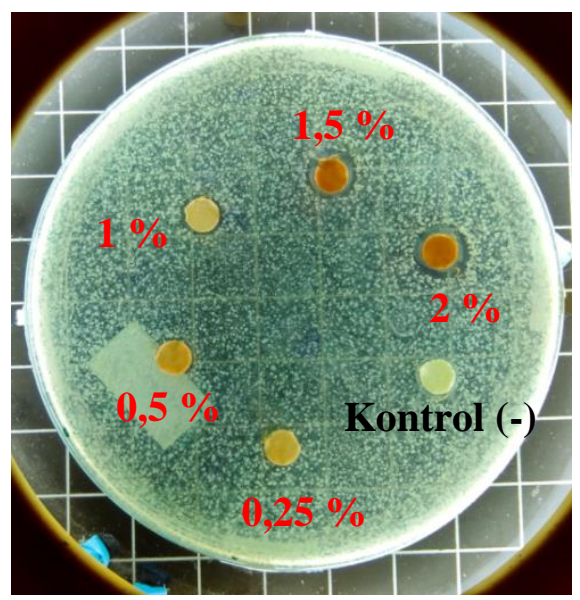

Gambar 3. Aktivitas Antibakteri Fraksi n-butanol Kulit Batang Libo terhadap bakteri E.coli

Setelah dilakukan pengujian, kemudian diukur diameter zona bunuh menggunakan mikrometer sekrup. Berikut data hasil pengukuran diameter zona bunuh pada ekstrak metanol kulit batang libo.

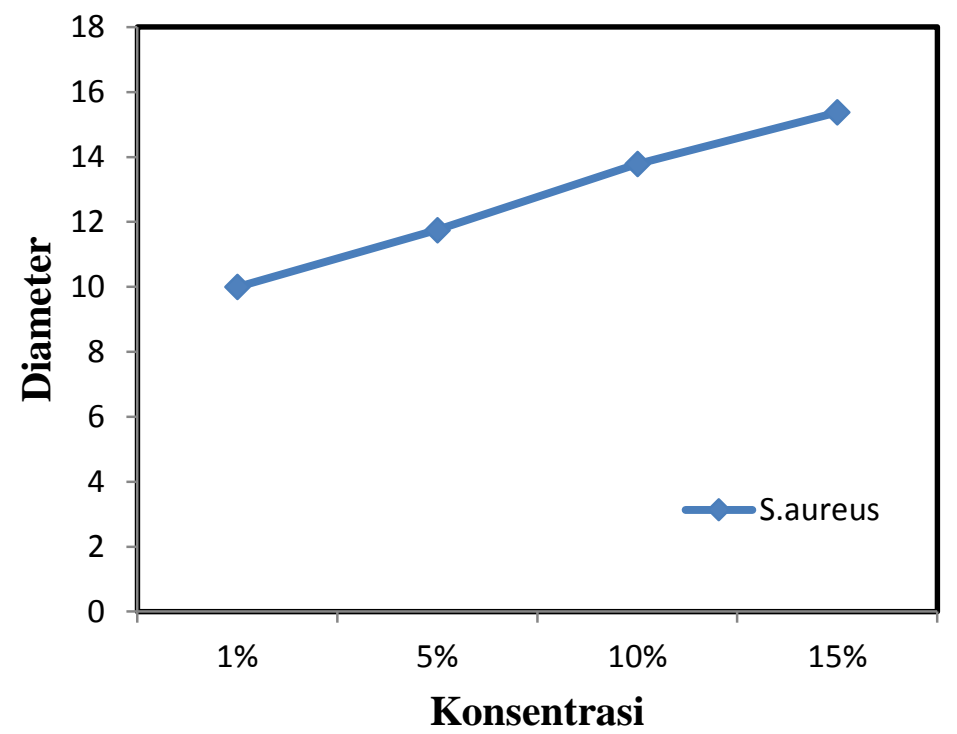

Grafik 1. Aktivitas Antibakteri Ekstrak Metanol Kulit Batang Libo

Berdasarkan data diatas diketahui bahwa semakin tinggi konsentrasi ekstrak maka diameter zona bunuh juga semakin meningkat. Sedangkan pada kontrol negatif tidak terdapat adanya zona hambat atau zona bunuh pada bakteri. Diameter zona bunuh yang terbentuk pada ekstrak metanol berkisar antara 10-15mm. Ekstrak metanol kulit batang libo memiliki aktivitas antibakteri yang sedang hingga kuat. Hal ini sesuai dengan ketentuan Davis dalam Rahayu (2009), bahwa daerah hambat atau zona bunuh $20 \mathrm{~mm}$ atau lebih memiliki potensi antimikroba sangat kuat, 10-20 mm berpotensi kuat, 5-10 mm berpotensi sedang dan kurang dari $5 \mathrm{~mm}$ berpotensi lemah. Kemudian dilanjutkan analisis 
dengan metode varian (anava) untuk mengetahui adanya pengaruh variasi konsentrasi ekstrak kulit batang libo terhadap pertumbuhan bakteri uji dan dilanjutkan dengan Uji Beda Nyata Jujur Duncan (BNJD). Pada hasil analisis One Way ANAVA diperoleh hasil bahwa variasi konsentrasi ekstrak metanol kulit batang libo memiliki perbedaan yang signifikan $(\mathrm{p}<0,05)$ terhadap zona bunuh S.aureus. Kemudian dilanjutkan analisis menggunakan Uji BNJD dimana hasil yang diperoleh adalah tidak adanya perbedaan yang signifikan antara konsentrasi $10 \%$ dan $15 \%$ sehingga konsentrasi efektif untuk ekstrak metanol kulit batang libo adalah $10 \%$.

Hasil analisis untuk fraksi n-butanol kulit batang libo terhadap bakteri Staphylococcus aureus dan Eschericia coli dapat dilihat pada Grafik berikut

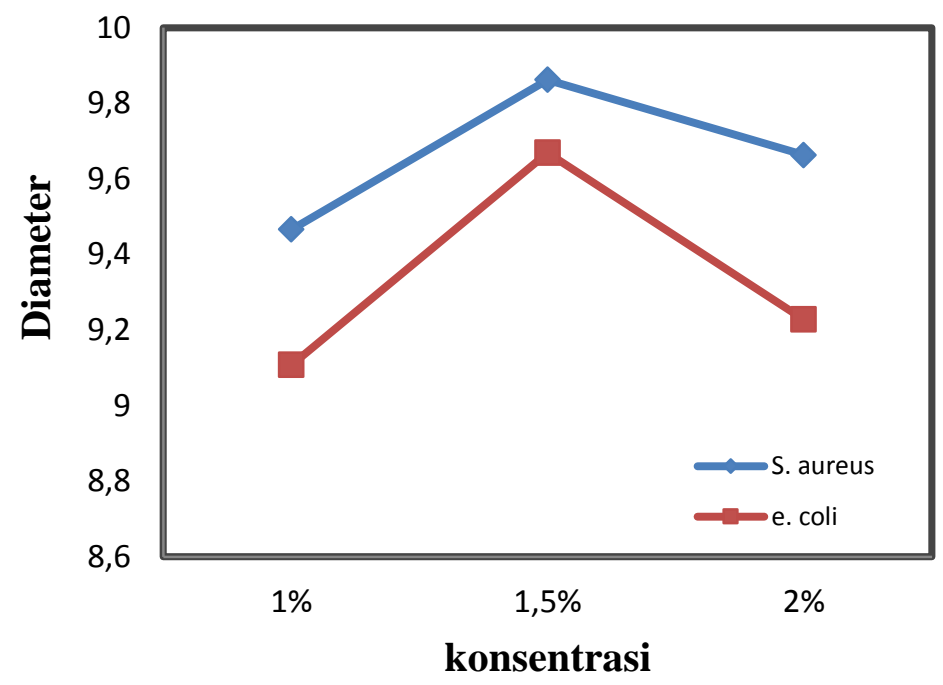

Grafik 2. Aktivitas Antibakteri Fraksi n-Butanol Kulit Batang Libo

Grafik diatas menunjukkan bahwa semakin tingginya konsentrasi maka diameter zona bunuh juga semakin meningkat. Hal ini terlihat pada konsentrasi $1 \%$ dan $1,5 \%$. Namun terjadi penurunan aktivitas pada konsentrasi $2 \%$. Hal ini mungkin disebabkan karena adanya kekentalan konsentrasi (viskositas) yang pekat, sehingga mempengaruhi penyerapan atau difusi ekstrak kedalam medium dan aktivitas antibakteri yang dihasilkan menjadi lebih kecil dibanding konsentrasi lainnya. Hasil pengujian kemudian dianalisis menggunakan One Way ANAVA untuk mengetahui pengaruh variasi konsentrasi fraksi nbutanol terhadap diameter zona bunuh bakteri. Berdasarkan analisis menggunakan anava, diketahui bahwa tidak adanya perbedaan yang signifikan $(\mathrm{p}>0,05)$ antara variasi konsentrasi ekstrak uji terhadap diameter zona bunuh baik pada E.coli maupun S.aureus. Hal ini mungkin dikarenakan rentang konsentrasi yang digunakan terlalu kecil sehingga aktivitas yang dihasilkan juga tidak berbeda nyata. Fraksi n-butanol memiliki aktivitas antibakteri dalam kategori sedang dimana diameter yang dihasilkan antara 9-10mm. Grafik menunjukkan aktivitas antibakteri fraksi n-butanol kulit batang libo lebih besar terhadap bakteri Staphylococcus aureus dibandingkan bakteri Escherichia coli. Diduga senyawa yang terkandung dalam fraksi n-butanol merupakan senyawa polar sehingga bakteri Staphylococcus aureus yang merupakan bakteri gram positif dan memiliki dinding penyusun peptidoglikan yang lebih tebal membuat senyawa polar pada fraksi n-butanol lebih mudah berikatan dengan dinding sel bakteri. 


\section{KESIMPULAN}

Pada penelitian ini diperoleh kesimpulan bahwa ekstrak metanol kulit batang libo mengandung alkaloid, fenol dan tanin serta ekstrak metanol dan fraksi n-butanol kulit batang libo memiliki aktivitas antibakteri terhadap Eschericia coli dan Staphylococcus aureus.

\section{DAFTAR PUSTAKA}

1. Darmadi (2008). Infeksi nosokomial: problematika dan pengendaliannya. Jakarta: Salemba Medika

2. Jawetz, Melnick. 2001. Mikrobiologi Kedokteran : Edisi 1. Jakarta : Salemba Medika

3. Gladwin, M., Trattler, B., 2011, Clinical Microbiology: Made Ridiculously Simple Edition 5, International journal of infectious diseases : IJID : official publication of the International Society for Infectious Diseases

4. Rijai, Laode. 2013. Potensi Tumbuhan Libo (Ficus variegata Blume) Sebagai Sumber Bahan Farmasi Potensial J. Trop. Pharm. Chem. 2. (3). 166-179. DOI: https://doi.org/10.25026/jtpc.v2i3.63

5. Sarker, S. D. dan Lutfun N. 2009. Kimia Untuk Mahasiswa Farmasi, Bahan Kimia Organik, Alam dan Umum. Pustaka Pelajar: Yogyakarta.

6. Sangi, M., Runtuwene. 2008. Analisis Fitokimia Tumbuhan Obat di Kabupaten Minahasa Utara. Chemistry Progress. 1:47-53.

7. Rahayu, S. 2009. Pengaruh Perbandingan Berat Bahan dan Waktu Ekstraksi. Terhadap Minyak Biji Pepaya Terambil. Journal Industri dan Informasi. Vol 4. No 5

8. Febrina, L, Rusli, R., Muflihah, F., 2015. Optimalisasi Ekstraksi dan Uji Metabolit Sekunder Tumbuhan Libo (Ficus variegate blume). J. Trop. Pharm. Chem. Vol 3. No. 2. 74-81. DOI: https://doi.org/10.25026/jtpc.v3i2.153 